\title{
Isolation and Characterization of Bovine Lymphocyte Nuclear Matrix
}

\author{
Hiroshi Nakayasu and Kiyoshi Ueda \\ Department of Medical Biochemistry, Shiga University of Medical Science, Seta, \\ Otsu 520-21, Japan
}

\begin{abstract}
A nuclear matrix was obtained from isolated nuclei of bovine lymphocyte by digestion with DNase I and subsequent extractions with $0.4 \mathrm{M}$ and $2.0 \mathrm{M} \mathrm{NaCl} .91 .1 \%$ of the nuclear protein, $99.5 \%$ of the DNA and $83.1 \%$ of the RNA were removed from isolated nuclei by these treatments. with the following nuclease digestion, almost all residual DNA and RNA was removed leaving the nuclear protein matrix.

Ultrastructural analysis of the nuclear matrix revealed a spherical structure containing a peripheral lamina, an internal fibrogranular network and residual nucleoli.

Sodium dodecyl sulfate polyacrylamide gel electrophoresis of the nuclear matrix demonstrated three major polypeptides of $68,000,53,000$ and 43,000 dalton as well as more than 50 minor polypeptides of various molecular weight classes. The 68,000 dalton polypeptide corresponds to lamin B, one of three predominant polypeptide components of rat liver nuclear matrix. However, polypeptides corresponding to lamin $\mathrm{A}$ and $\mathrm{C}$ were not detectable in the bovine lymphocyte nuclear matrix.
\end{abstract}

Berezney and Coffey $(4,6)$ were the first to propose that a proteinaceous network, termed the nuclear matrix, serves as the skeletal foundation which determines the overall organization of rat liver nuclei. Since then, some proteinaceous structures, resembling a nuclear matrix, have been prepared from HeLa $\mathrm{S}_{3}$ cell (15), Tetrahymena (30), Friend erythroleukemia cell (19), Physarum polycephalum (25), 3T6 fibroblast (9) and others. These proteinaceous structures are very similar to each other, composed of three components: peripheral lamina, internal fibrogranular structure and residual nucleoli. The nuclear matrix appears to be a ubiquitous structure that is present in almost all eukaryotic cells. Much evidence is accumulating to suggest that the nuclear matrix not only may function as the skeleton of the nucleus but also may be associated with many dynamic aspects of nuclear function: nuclear swelling $(30,31)$, DNA replication $(5,7,13,16,27)$, RNA transcription $(1,11,23)$, hormone binding (3), T-antigen binding (9), processing and transport of RNA $(22,29)$, etc.

To know the real function of the nuclear matrix, it is important to examine the matrix in cells from a variety of organisms and tissues. In this paper, we first report the isolation method and characterization of the bovine lymphocyte nuclear matrix.

Abbreviations: SDS, sodium dodecyl sulfate, PMSF, phenyl methyl sulfonyl fluoride; DEP, diethyl pyrocarbonate; GTM buffer, $50 \mathrm{mM}$ Tris- $\mathrm{HCl}(\mathrm{pH} 7.5)$ containing $25 \%(\mathrm{v} / \mathrm{v})$ glycerol and $2 \mathrm{mM} \mathrm{MgCl}_{2}$. 


\section{MATERIALS AND METHODS}

Lymphocyte nuclei. Lymphocytes used in these experiments were isolated from bovine submaxillary lymph nodes. Routinely 3-6 lymph nodes from adult cattle were dissected from surrounding tissue and finely minced with a cutting knife. The minced tissue was sus-

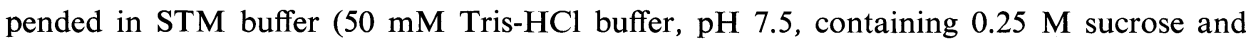
$5 \mathrm{mM} \mathrm{MgCl} 2$ ) and gently stirred. Then, connective tissue and other debris were removed by filtration through four layers of gauze. The lymphocyte suspension thus obtained was centrifuged at $100 \times \mathrm{g}$ for $10 \mathrm{~min}$. The resulting cell pellet was washed once in the buffer. The washed lymphocytes (50 mg DNA) were suspended in $25 \mathrm{ml}$ of STM buffer, containing $1 \%$ Triton X-100, $1 \mathrm{mM}$ PMSF and $0.1 \%$ DEP. The cells were disrupted by passing the suspension through a syringe needle $(0.65 \times 30 \mathrm{~mm})$ four times. Then the homogenate was centrifuged at $200 \times \mathrm{g}$ for $5 \mathrm{~min}$, and the supernate (Triton X-100 supernate) was removed. The resulting nuclear pellet was resuspended in the STM buffer, containing $1 \%$ Triton X-100, $1 \mathrm{mM}$ PMSF and $0.1 \% \mathrm{DEP}$, and subjected to cell homogenization in the same manner for two more times and finally centrifuged at $200 \times \mathrm{g}$ for $5 \mathrm{~min}$. The nuclei obtained were essentially free of cytoplasmic contamination as judged by electron microscopy.

Nuclear matrix. The procedure for the isolation of bovine lymphocyte nuclear matrix is presented in detail in the RESULTS section. All mediums for isolation contained $1 \mathrm{mM}$ PMSF and $0.1 \%(\mathrm{v} / \mathrm{v})$ DEP to inhibit some protease and RNase activity, respectively. The preparation steps were conducted at $0-4^{\circ} \mathrm{C}$. Rat liver nuclear matrix prepared as previously (20) was kindly provided by Dr. H. Ueyama, of our laboratory.

Preparation of an RNase-depleted DNase. Commercial pancreatic DNase (DN-CL, purchased from Sigma) was further purified to remove a contaminating RNase. This was carried out by affinity chromatography on Agarose-UMP (obtained from Miles laboratories) according to the procedure of Brison and Chambon (8). The purified preparation of DNase was essentially "RNase-free".

Electron microscopy. Samples were prepared for electron microscopy by fixation in $3.2 \%$ glutaraldehyde $\left(0.1 \mathrm{M}\right.$ sodium cacodylate buffer, $\left.\mathrm{pH} 7.2,5 \mathrm{mM} \mathrm{MgCl}_{2}\right)$ at $4{ }^{\circ} \mathrm{C}$ overnight. They were then centrifuged at $400 \times \mathrm{g}$ for $5 \mathrm{~min}$ and the pellets were post-fixed with $1 \%$ osmium tetroxide $(0.1 \mathrm{M}$ sodium cacodylate buffer, $\mathrm{pH} 7.2,5 \mathrm{mM} \mathrm{MgCl} 2)$ at $0^{\circ} \mathrm{C}$ for $2 \mathrm{~h}$. The specimens were dehydrated with ethanol and embedded in an Epon 812 mixture. Thin sections were double-stained with uranyl acetate and lead citrate solutions. Electron micrographs were made with a Hitachi $\mathrm{H}-600$ electron microscope at an original magnification ranging from $\times 5,000$ to $\times 20,000$.

SDS-Polyacrylamide gel electrophoresis. All electrophoretic analyses were performed in $1 \mathrm{~mm}$ thick slab gels according to the procedure of O'Farrell (26). The gels used were composed of a $4.5 \%$ acrylamide stacking gel overlaying a $13.5 \%$ acrylamide separation gel. The acrylamide/bisacrylamide ratio was maintained at $1: 0.027$ in both the stacking and separation gels. Lymphocyte and lymphocyte nuclei were solubilized (about $4 \mathrm{mg}$ protein/ml) in lysis buffer ( $0.1 \mathrm{M}$ Tris- $\mathrm{HCl}$ buffer, $\mathrm{pH} 7.5$, containing $2 \%$ SDS and $4 \mathrm{M}$ urea) then centrifuged at $60,000 \mathrm{rpm}$ for $16 \mathrm{~h}$ to precipitate the bulk of the DNA. The other samples were solubilized in the lysis buffer without centrifugation. They were boiled at $100^{\circ} \mathrm{C}$ for $3 \mathrm{~min}$ with $\beta$-mercaptoethanol $(10 \%)$ and bromophenol blue $(0.01 \%)$. Following electrophoresis, the slab gels were stained with coomassie blue R-250 and destained in $10 \%(\mathrm{v} / \mathrm{v})$ acetic acid, containing $20 \%(\mathrm{v} / \mathrm{v})$ methanol.

Determination of DNA, RNA and Protein. DNA, RNA and protein were determined by the method of Burton (10) with calf thymus DNA as standard, by orcinol reaction (28) with yeast RNA as the standard and by the method of Lowry et al. (21) with bovine serum 
albumin as the standard, respectively. However, the DNA content of the lymphocytes was analyzed fluorometrically (18) in order to rapidly prepare the nuclear matrix.

\section{RESULTS}

Isolation of bovine lymphocyte nuclear matrix and nuclear protein matrix. Berezney and Coffey (4) first described the isolation of nuclear matrix from rat liver. The bulk of nuclear DNA was removed during low magnesium treatment in that case. However, bovine lymphocyte nuclei were burst away by treatment in low magnesium buffer. Thus, we employed a DNase treatment in the presence of $2 \mathrm{mM} \mathrm{MgCl}_{2}$ in the first step. The latter method always resulted in the successful preparation of lymphocyte nuclear matrix as follows: Lymphocyte nuclei ( $50 \mathrm{mg}$ DNA) were suspended in $20 \mathrm{ml}$ of GTM buffer ( $50 \mathrm{mM}$ Tris- $\mathrm{HCl}$ buffer, $\mathrm{pH} 7.5$, containing $25 \%(\mathrm{v} / \mathrm{v})$ glycerol and $2 \mathrm{mM} \mathrm{MgCl}_{2}$ ). The suspension was incubated at $25^{\circ} \mathrm{C}$ for $30 \mathrm{~min}$ with $1 \mathrm{mg}$ of purified DNase I. Then the suspension was centrifuged at $400 \times \mathrm{g}$ for $30 \mathrm{~min}$ and the supernate (Ds) was removed. The white pellet (DNase treated nuclei) was suspended in $8 \mathrm{ml}$ of GTM buffer by Pasteur pipette. To this suspension, $32 \mathrm{ml}$ of GTM buffer containing $0.5 \mathrm{M} \mathrm{NaCl}$ was slowly added, with gentle shaking, to a final concentration of $0.4 \mathrm{M}$. After incubation on ice for $10 \mathrm{~min}$, the suspension was centrifuged at $600 \times \mathrm{g}$ for $90 \mathrm{~min}$. The supernate (Hs 1) was carefully removed and the resulting translucent pellet (low salt nuclear matrix) was mildly suspended in $8 \mathrm{ml}$ of GTM buffer containing $2 \mathrm{M} \mathrm{NaCl}$. It was incubated on ice for $10 \mathrm{~min}$ and centrifuged at $600 \times \mathrm{g}$ for $20 \mathrm{~min}$. The supernate (Hs 2) was removed and the resulting pellet (nuclear matrix) was suspended in $2.5 \mathrm{ml}$ of GTM buffer. The nuclear matrix was stored at $-20^{\circ} \mathrm{C}$ for a few days without structural alteration.

For preparation of the nuclear protein matrix, the pellet of nuclear matrix obtained was suspended in $8 \mathrm{ml}$ of GTM buffer without the addition of DEP, and centrifuged at $600 \times \mathrm{g}$ for $20 \mathrm{~min}$. This washing was repeated once more to remove DEP which inhibits the RNase activity. The pellet was suspended in $8 \mathrm{ml}$ of GTM buffer, then $0.5 \mathrm{mg}$ of purified DNase, $0.5 \mathrm{mg}$ of RNase A and PMSF (at a final concentration of $1 \mathrm{mM}$ ) were added to the suspension. After incubation at $25^{\circ} \mathrm{C}$ for $20 \mathrm{~min}$, the suspension was centrifuged at $600 \times \mathrm{g}$ for $20 \mathrm{~min}$. The final pellet (nuclear protein matrix) was carefully suspended in $2.5 \mathrm{ml}$ of GTM buffer. A flow diagram for isolation of the nuclear protein matrix is shown in Fig. 1.

During the subsequent extraction procedure, $95-99 \%$ of the total nuclear DNA

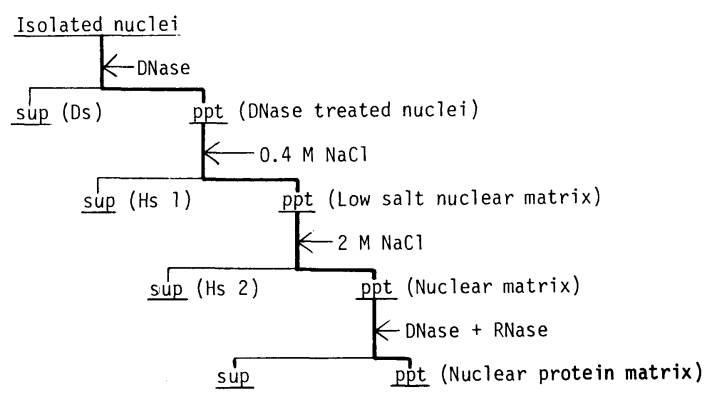

Fig. 1. Scheme for the subfraction of isolated lymphocyte nuclei yielding a nuclear matrix and a nuclear protein matrix. For detail, see RESUlTs. 
TABLE 1. STEPS IN THE ISOLATION OF NUClEAR MATRIX

\begin{tabular}{lllccc}
\hline Step & Consecutive extractions & Resultant nuclear sphere & \multicolumn{3}{c}{ Total nuclear material extracted } \\
\cline { 3 - 6 } & & & $\begin{array}{c}\text { Protein } \\
(\%)\end{array}$ & $\begin{array}{c}\text { DNA } \\
(\%)\end{array}$ & $\begin{array}{c}\text { RNA } \\
(\%)\end{array}$ \\
\hline 0. & Isolation of nuclei & Isolated nuclei & 0 & 0 & 0 \\
1. & DNase treatment & DNase treated nuclei & $10.1 \pm 0.9$ & $18.5 \pm 0.4$ & $33.4 \pm 3.8$ \\
2. & $0.4 \mathrm{M} \mathrm{NaCl}$ treatment & Low salt nuclear matrix & $77.7 \pm 5.7$ & $95.3 \pm 0.2$ & $70.7 \pm 2.8$ \\
3. & $2 \mathrm{M} \mathrm{NaCl}$ treatment & Nuclear matrix & $91.1 \pm 0.1$ & $99.5 \pm 0.1$ & $83.1 \pm 1.8$ \\
4. & Nucleases treatment & Nuclear protein matrix & $92.0 \pm 1.4$ & $>99.9$ & $98.7 \pm 0.3$
\end{tabular}

Each value is the mean \pm standard deviation of three determinations.

was removed (Table I). The residual DNA, however, was tightly bound to the nuclear matrix, which is resistant to the exhaustive DNase digestion, as shown in Fig. 2. The residual DNA was removed by the following DNase-RNase treatment, while a small amount of RNA remained attached to the nuclear protein matrix. The procedure for isolation of the matrix removed most of the histones, leaving about $10 \%$ of the total nuclear proteins. The recovery of proteins from nuclei during consecutive extractions is summarized in Table I, and the polypeptide composition of each subfraction will be described later.

Phase-contrast microscopy and electron microscopy studies. Figure 3 shows the lymphocyte and nuclear spheres observed with a phase-contrast microscope at each

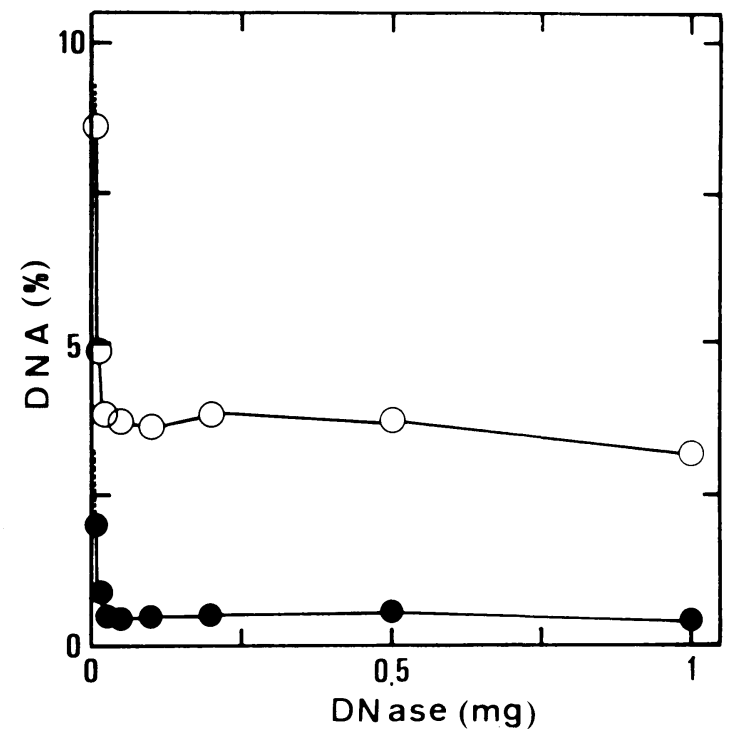

Fig. 2. The remains of DNA in the low salt nuclear matrix and nuclear matrix after digestion with DNase I. Lymphocyte nuclei (5.6 mg DNA) were suspended in $2 \mathrm{ml}$ of GTM buffer, containing $1 \mathrm{mM}$ PMSF and $0.1 \%$ DEP and incubated at $25^{\circ} \mathrm{C}$ for $30 \mathrm{~min}$ with an indicated amount of purified DNase I. The low salt nuclear matrix and the nuclear matrix were prepared as described in RESULTS. Remaining DNA in the low salt nuclear matrix (- $-{ }_{-}$) and the nuclear matrix ( $-\longrightarrow-$ ) were determined by the method of Burton (10). The values are represented as a percentage of the total nuclear DNA. 
step of the above extraction procedure. The round shape was maintained throughout the steps. The presence of glycerol in the extraction medium was essential for holding the structures. Without glycerol, considerable nuclear spheres turned to fibrous fragments because of destabilization. As shown in Fig. 3, the mean diameter \pm standard deviation of lymphocyte, isolated nuclei, DNase treated nuclei, low salt nuclear matrix and nuclear matrix were $2.94 \pm 0.40,2.53 \pm 0.30,1.73 \pm 0.29,1.45 \pm 0.27$ and $1.62 \pm 0.32 \mu \mathrm{m}$, respectively. The shape of the nuclear protein matrix was not mentioned in Fig. 3, since it showed too faint an image with phase-contrast microscopy. But the diameter of the nuclear protein matrix was roughly similar to that of the nuclear matrix. Significant decrease in the diameter of nuclei was observed by DNase treatment. It is surprising that DNase treated nuclei held their round shape in spite of considerable shrinking (about 30\% of diameter and $70 \%$ of volume) due to digestion.

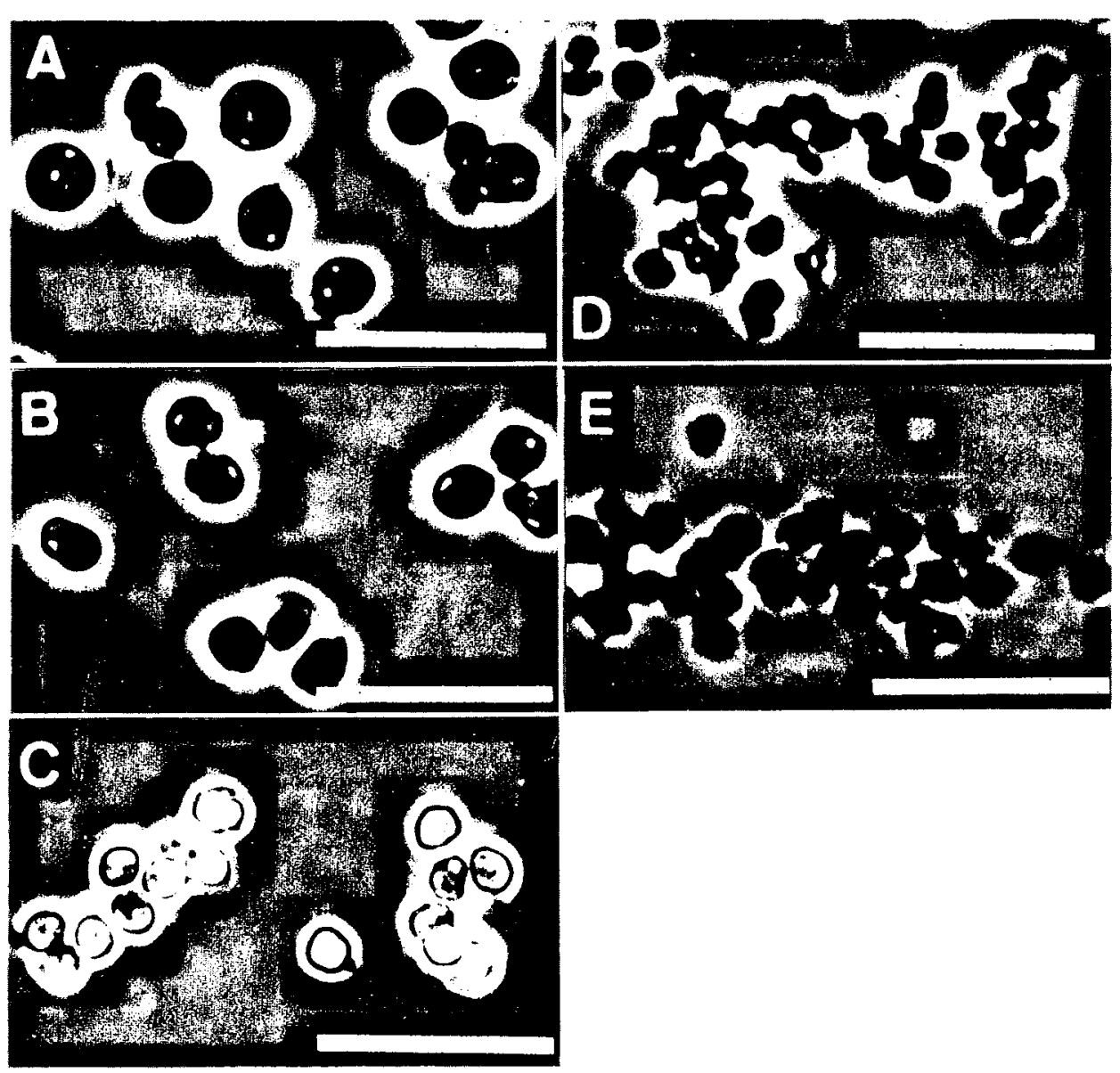

Fig. 3. Phase-contrast microscopy of lymphocytes (A), isolated nuclei (B), DNase treated nuclei (C), low salt nuclear matrix (D) and nuclear matrix (E). One or two drops of these samples were suspended in $1 \mathrm{ml}$ of STM buffer immediately after prepararion. Bar $=10 \mu \mathrm{m}$. The mean diameters \pm standard deviation (from 100 spheres) of these fractions: lymphocyte, isolated nuclei, DNase treated nuclei, low salt nuclear matrix and nuclear matrix, are $2.94 \pm 0.40,2.53 \pm 0.30,1.73 \pm 0.29,1.45 \pm 0.27$ and $1.62 \pm 0.32 \mu \mathrm{m}$, respectively. 



Fig. 4. Electron microscopy of lymphocyte (A), isolated nuclei (B), DNase treated nuclei (C), low salt nuclear matrix (D), nuclear matrix (E) and nuclear protein matrix (F). All samples were fixed and stained as described in MATERIALS AND METHODS. Bar $=2 \mu \mathrm{m}$.

Ultrastructural morphologies of lymphocyte and nuclear spheres were shown in Fig. 4. Electron micrographs of these fractions also revealed the maintenance of round nuclear shapes. The attachment of granular particles to the surface of spheres is shown in DNase treated nuclei (C). These particles may be material released by DNase digestion. The surface lamina, internal fibrogranular structure and residual nucleoli are clearly shown in the nuclear matrix (E) and in the low salt nuclear matrix (D). However, densely stained nucleoli are hardly shown in the nuclear protein matrix (F).

The nuclear pore complex was easily shown in electron micrographs of untreated (B) and DNase treated nuclei (C). However, it was rather difficult to distinguish the pore complex from surface structures in the electron micrographs of the low salt nuclear matrix (D), the nuclear matrix (E) and the nuclear protein matrix (F). Internal fibrogranular structures are recognizable first in the low salt nuclear matrix (D). The quantity of the fibrogranules decrease as the extraction steps proceed. This may be related to a removal of nucleic acids from low salt nuclear matrix by salt washing and by nucleases digestion.

$S D S$-polyacrylamide gel electrophoresis of matrix proteins. SDS-polyacrylamide gel electrophoresis of nuclear matrix and other subfractions are compared in Fig. 5. Low salt $(0.4 \mathrm{M} \mathrm{NaCl})$ extraction caused complete loss of $\mathrm{H} 1$ histone with only a partial loss of histone cores from DNase digested nuclei. Almost complete removal 


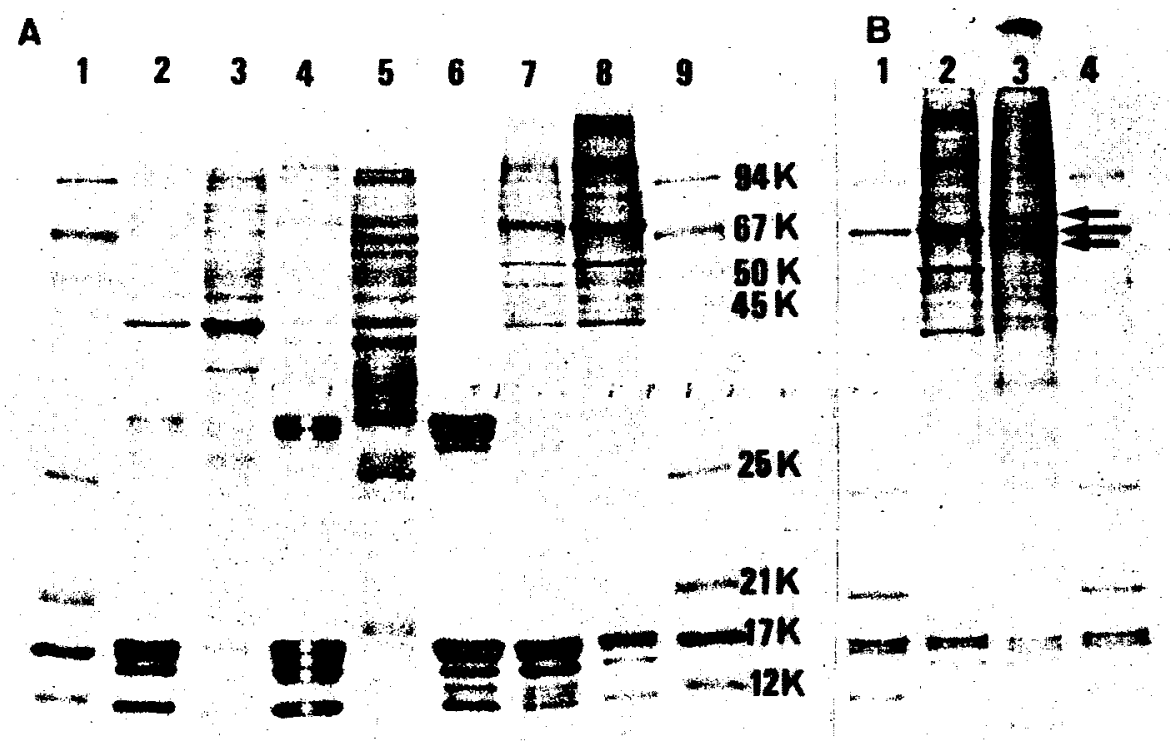

Fig. 5. SDS-polyacrylamide gel electrophoresis of the nuclear matrix polypeptides. Each sample was treated before electrophoresis as described in the text. A. 1 and 9 ; molecular weight markers, 2; lymphocyte, 3; Triton X-100 supernate, 4; isolated nuclei, 5; Ds, 6; Hs 1, 7; low salt nuclear matrix, 8; nuclear matrix. Histone bands are indicated by asterisks. B. 1 and 4; molecular weight markers, 2; bovine lymphocyte nuclear matrix, 3; rat liver nuclear matrix. Rat liver nuclear lamins are indicated by arrows (lamin A, 70,000, lamin B, 68,000, lamin C, 65,000). The molecular weight markers used were phosphorylase-a $(94,000)$, bovine serum albumin $(67,000)$, Ig $G$ heavy chain $(50,000)$, ovalbumin $(45,000)$, chymotrypsinogen $(25,000)$, trypsin inhibitor $(21,000)$, myoglobin $(17,000)$ and cytochrome $c(12,000)$.

of these cores was obtained by subsequent high salt $(2.0 \mathrm{M} \mathrm{NaCl})$ treatment, leaving matrix proteins. Low salt nuclear matrix (lane 7) and nuclear matrix (lane 8 ) are characterized by three major polypeptide bands with a molecular weight of 68,000 , 53,000 and 43,000 dalton. The 68,000 polypeptide had the same mobility with lamin $\mathrm{B}$ from rat liver nuclei on SDS-polyacrylamide gel electrophoresis as shown in Fig. $5 \mathrm{~B}$. The results suggest that the 68,000 polypeptide is related to lamins which are the major components of nuclear matrix from several sources $(6,9,14)$. One of the prominent proteins in the nuclear matrix $(43,000$ dalton) is also clearly observed in lymphocytes (lane 2), Triton X-100 supernatant (lane 3), isolated nuclei (lane 4) and Ds (lane 5). This abundant protein may be actin, which is a major protein component of lymphocyte. The electrophoretical pattern of the nuclear protein matrix is not shown in Fig. 5, but it was extremely similar to that of the nuclear matrix (lane 8).

\section{DISCUSSION}

Isolation of nuclear matrix. We have developed a procedure allowing the isolation of a nuclear matrix from a bovine lymphocyte by low and high salt extractions including preincubation with DNase I. In the process of isolation, the nuclear matrix 
spheres are significantly decreased in size, while the size of isolated lymphocyte nuclei closely resembles the in situ diameters. This shift to smaller sizes occurs after DNase treatment. A similar contraction of the nuclear matrices was also reported in HeLa cells (15) and in rat liver (6). Hodge et al. (15) reported that the nuclear matrix had a spherical shape having $70 \%$ of the diameter of the original nuclei $\left(\mathrm{HeLa} \mathrm{S} \mathrm{S}_{3}\right.$ cell) which is in agreement with our results. Berezney and Coffey also described nuclear matrix shrinking by nuclease digestion (6). Wunderlich and Herlan (30) isolated a nuclear matrix from Tetrahymena pyriformis which reversibly contracts at varying concentrations of the bivalent cations, $\mathrm{Ca}^{2+}$ and $\mathrm{Mg}^{2+}$. Therefore, the possible contractive nature of nuclear matrix may be related to some dynamic transformation of the nuclei.

Electron microscopy reveals that the nuclear matrix obtained from bovine lymphocyte still shows the nuclear sphere shape and is composed of a surrounding nuclear lamina, internal fibrogranular structures and residual nucleoli. These ultsastructures of the nuclear matrix are extremely similar to those of other sources: nuclear matrix from rat liver (6), HeLa $S_{3}$ cells (15), Friend erythroleukemia cells (19) and 3T3 fibroblasts (27).

The nuclear matrix obtained was mainly composed of proteins containing small amounts of DNA and considerable amounts of RNA. These results agree with those of nuclear matrices from other sources $(2,6,25,30)$. The significance of these residual nucleic acids is uncertain at present, but there are many reports describing the association of a newly synthesized DNA with nuclear matrices $(5,7,9,13,16,27)$. On the other hand, Miller et al. found heterogeneous nuclear RNA (23) and small nuclear RNA (24) associated with rat liver nuclear skeleton. Clawson and Smuckler (11) also showed the idea that heterogeneous nuclear RNA may be processed after attachment to the nuclear envelope or nuclear matrix. Studies must be advanced on these associated polynucleotides of the nuclear matrix, so that the nuclear matrix may contribute to many nuclear functions.

Proteins of the nuclear matrix. Three major protein bands $(68,000,53,000$ and 43,000 ) are revealed by SDS-polyacrylamide gel electrophoresis of bovine lymphocyte nuclear matrix (Fig. 5A). As indicated above, the 68,000 protein may correspond to one of the three major protein components of rat liver nuclear matrix $(69,000,66,000$ and $62,000)(6)$ or nuclear pore complex-lamina $(70,000,66,000$ and 62,000$)(14)$. Likewise in rat liver nuclear matrix, three prominent protein bands $(60,000-75,000)$ related to lamin, were usually detected on SDS-gel analysis of nuclear matrix from other sources $(9,12,25,30)$. However, recent studies of the nuclear matrix polypeptides from other cells indicate possible differences in molecular weights. For example, Long et al. reported that only two prominent polypeptide bands $(66,000$ and 62,000$)$ were detected in isolated matrix from Friend erythroleukemia cells (19), while Krohne et al. reported that only one prominent polypeptide $(73,000)$ was detected in nuclear ghosts from oocytes of Xenopus laevis (17). Therefore, it is not strange that only one major polypeptide migrates between $60,000-75,000$ dalton on SDS-gel analysis of bovine lymphocyte nuclear matrix. These results, however, may not rule out the possible heterogeneity of 68,000 protein(s) of the nuclear matrix.

There are many non-histone protein bands (more than 50 bands) in addition to lamin found on SDS-gel analysis of lymphocyte nuclear matrix protein. For the present, the nature of these proteins is not made sufficiently clear. However, an abundant protein with a molecular weight of 43,000 dalton may be actin as judged by its molecular weight. 
Acknowledgement. We are grateful to Dr. T. Matsuura, Dr. H. Ueyama and Mrs. Y. Yoshimura for their stimulating discussions. We also thank Mr. S. Nishitani and Mr. T. Nakagawa for the electron microscopy.

\section{REFERENCES}

1. Agutter, P. S. and K. Birchall. Functional differences between mammalian nuclear protein matrices and pore-lamina complex laminae. Exp. Cell Res. 124, 453-459, 1979

2. Agutter, P. S. and J. C. W. Richardson. Nuclear non-chromatin proteinaceous structures: Their role in the organization and function of the interphase nucleus. J. Cell Sci. 44, 395-435, 1980

3. BARrack, E.R. and D.S. CofFEY. The specific binding of estrogens and androgens to the nuclear matrix of sex hormone responsive tissues. J. Biol. Chem. 255, 7265-7275, 1980

4. BerEzneY, R. and D.S. CofFEY. Identification of a nuclear protein matrix. Biochem. Biophys. Res. Commun. 60, 1410-1417, 1974

5. Berezney, R. and D.S. CofFeY. Nuclear protein matrix: Association with newly synthesized DNA. Science 189, 291-293, 1975

6. BerEZneY, R. and D.S. Coffey. Nuclear matrix. Isolation and characterization of a framework structure from rat liver nuclei. J. Cell Biol. 73, 616-673, 1977

7. BEREZnEy, R. Effect of protease inhibitors on matrix proteins and the association of replicating DNA. Exp. Cell Res. 123, 411-414, 1979

8. Brison, O. and P. ChAmbon. A simple and efficient method to remove ribonuclease contamination from pancreatic deoxyribonuclease preparations. Anal. Biochem. 75, 402-409, 1976

9. Buckler-White, A.J., G.W. Humphrey and V. Pigiet. Association of polyoma T antigen and DNA with the nuclear matrix from lytically infected 3T6 cells. Cell 22, 37-46, 1980

10. Burton, K. Determination of DNA concentration with diphenylamine. in Methods in Enzymology, Vol. 12 B, ed. Grossman, L. and K. Moldave, Academic Press, New York, pp. 163-166, 1968

11. Clawson, G.A. and E.A. Smuckler. On the nature of nuclear envelope-associated RNA. Biochem. Biophys. Res. Commun. 96, 812-816, 1980

12. Cobis, C.S. and K.R. Shelton. Major oligomeric structural proteins of the HaLa nucleus. Arch. Biochem. Biophys. 189, 323-335, 1978

13. Dijkwell, P.A., L. Mullender and F. WANKA. Analysis of the attachment of replicating DNA to a matrix in mammalian interphase nuclei. Nuc. Acids Res. 6, 219-230, 1979

14. Gerace, L., A. Blum and G. Blobel. Immunocytochemical localization of the major polypeptides of the nuclear pore complex-lamina fraction. Interphase and mitotic distribution. J. Cell Biol. 79, 546-566, 1978

15. Hodge, L.D., P. Mancini, F. M.Davis and P. Heywood. Nuclear matrix of HeLa $S_{3}$ cells. Polypeptide composition during adenovirus infection and in phases of the cell cycle. J. Cell Biol. 72, 194-208, 1977

16. Hunt, B.F. and B. Vogelstein. Association of newly replicated DNA with the nuclear matrix of Physarum polycephalum. Nuc. Acids Res. 9, 349-363, 1981

17. Krohne, G., W.W. Franke and U. Scheer. The major polypeptides of the nuclear pore complex. Exp. Cell Res. 116, 85-102, 1978

18. Labarca, C. and K. Paigen. A simple, rapid and sensitive DNA assay procedure. Anal. Biochem. 102, 344-352, 1980

19. Long, B.H., C.-Y. HuAng and A.O. Pogo. Isolation and characterization of the nuclear matrix in Friend erythroleukemia cells: chromatin and hnRNA interaction with the nuclear matrix. Cell 18, 1079-1090, 1979

20. Matsuura, T., H. Ueyama, H. Nakayasu and K. Ueda. Isolation and characterization of the nuclear matrix from rat liver nuclei. Cell Struct. Funct. 6, 79-82, 1981

21. Lowry, O.H., N.J. Rosenbrough, A.L. Farr and R.J. Randall. Protein measurement with Folin phenol reagent. J. Biol. Chem. 193, 265-275, 1951 
22. McDonald, J.R. and P.S. Agutter. The relationship between polyribonucleotide binding and the phosphorylation of nuclear envelope protein. FEBS Lett. 116, 145-148, 1980

23. Miller, T.E., C.-Y. Huang and A.O. Pogo. Rat liver nuclear skeleton and ribonucleoprotein complexes containing hnRNA. J. Cell Biol. 76, 675-691, 1978

24. Miller, T.E., C.-Y. Huang and A.O. Pogo. Rat liver nuclear skeleton and small molecular weight RNA species. J. Cell Biol. 76, 692-704, 1978

25. Mitchelson, K.R., A.G.M. BeKers and F. WANKA. Isolation of a residual protein structure from nuclei of the myxomycete Physarum polycephalum. J. Cell Sci. 39, 247-256, 1979

26. O'Farrel, P.H. High resolution two-dimensional electrophoresis of proteins. J. Biol. Chem. 250, 4007-4021, 1975

27. Pardoll, D.M., B. Vogelstein and D.S. Coffey. A fixed site of DNA replication in eucaryotic cells. Cell 19, 527-536, 1980

28. SchneIDer, W.C. Determination of nucleic acid in tissues by pentose analysis. in Methods in Enzymology, Vol. 3, ed. Colowick, S.P. and N.O. Kaplan, Academic Press, New York, pp. 680-684, 1957

29. Steer, R.C., S.A. Goueli, M.J. Wilson and K. Ahmed. Cobalt-stimulated protein phosphokinase activity of the pore complex-lamina fraction from rat liver nuclear envelope. Biochem. Biophys. Res. Commun. 92, 919-925, 1980

30. Wunderlich, F. and G. Herlan. A reversibly contractile nuclear matrix. Its isolation, structure and composition. J. Cell Biol. 73, 271-278, 1977

31. Wunderlich, F., G. Giese and C. Bucherer. Expansion and apparent fluidity decrease of nuclear membranes induced by low $\mathrm{Ca} / \mathrm{Mg}$. Modulation of nuclear membrane lipid fluidity by the membrane-associated nuclear matrix proteins. J. Cell Biol. 79, 479-490, 1978

(Received for publication, May 6, 1981) 